\title{
Religious Officials' knowledge, attitude, and behavior towards smoking and the new tobacco law in Kahramanmaras, Turkey
}

\author{
Mustafa Haki Sucakli* ${ }^{*}$, Ali Ozer², Mustafa Celik, Hasan Kahraman³ and Hasan Cetin Ekerbicer ${ }^{4}$
}

\begin{abstract}
Background: Tobacco control effort should be first started in people that are looked upon as role models for the general population. We aimed to determine the knowledge, attitude, and behavior of religious officials towards smoking and the new tobacco law.

Method: The study group was comprised of 492 Imams and 149 Quran course instructors working in Kahramanmaras city of Turkey, 641 religious officials in total, and our survey form was applied on 406 (63.3\%) of those religious officials who agreed to participate in the study.

Results: Twenty-eight (6.9\%) participants were current smokers and 35 (8.6\%) were ex-smokers. 99.8\% of the religious officials believed that smoking was harmful and/or prohibited in terms of religion. While $43.6 \%$ respondents thought smoking was "haram" (forbidden by Islam), 56.2\% believed it was "makruh" (something regarded as reprehensible, though not forbidden by God according to Islam). $85.2 \%$ of the participants were aware of the recent tobacco law. 55.5\% of the respondents, who were aware of the recent tobacco law, evaluated their knowledge level on the law as adequate, whereas $44.5 \%$ evaluated it as inadequate $92.4 \%$ of the participants noted that religious officials should play active roles in tobacco control effort.

Conclusion: Smoking rate among religious officials is much lower than that of general public. In order to help religious officials to take a more active role on this issue, they should be trained on the subject and appropriate platforms should be established.
\end{abstract}

Keywords: Smoking, knowledge, attitude, behavior, Imam, religious official, Turkey

\section{Background}

Smoking is the most important preventable cause of death across the world [1]. Each year, 4 million $(8.8 \%$ of the entire mortality per year) people lose their lives due to smoking-related diseases [2]. Currently, cigarette smoking is a worldwide health issue, however, while it shows a decrease in developed countries, there is an increase in cigarette smoking rates in developing countries such as ours. The elevated prevalence is observed particularly among the young people [3]. Turkey stands as the second country after Greece in terms of per capita cigarette consumption [4] and appears to be the

\footnotetext{
* Correspondence: hakisucakli@gmail.com

'Department of Family Medicine, Medical Faculty, Kahramanmaras

Sutcuimam University, Kahramanmaras, Turkey

Full list of author information is available at the end of the article
}

fifth country with regard to world tobacco production [5].

As countries implement various precautions for tobacco control, international regulations on the subject are taking place, as well. Among those regulations, Framework Convention on Tobacco Control (FCTC) has a particular importance. This convention which was published by the World Health Organization (WHO) in 2003, has been designed as a treaty that compels ratifying countries to take specific legislative tobacco control actions [6]. In our country, this convention has been approved and enacted by Türkiye Büyük Millet Meclisi (TBMM) (Grand National Assembly of Turkey). In addition, Turkey has implemented the required regulations by issuing Law No. 4207 on "Prevention of harm induced by tobacco products" and Law No. 5727 on
Ciomed Central

() 2011 Sucakli et al; licensee BioMed Central Ltd. This is an Open Access article distributed under the terms of the Creative Commons Attribution License (http://creativecommons.org/licenses/by/2.0), which permits unrestricted use, distribution, and reproduction in any medium, provided the original work is properly cited. 
"Amendments on the law for prevention of harm induced by tobacco products" [7]. By this law, indoor smoking at public places has been prohibited completely since July 19, 2009.

The leadership of social role models (eg. healthcare workers, teachers, religious officials etc.) is an important part of a comprehensive national tobacco control effort. After succeeding in those people, they should be convinced to take active role in campaigns for smoking cessation. When we review the countries that succeeded against smoking, physicians and other workers are observed to have active roles [8,9]. If role models of the society smoke, it affects the tobacco control effort negatively. Therefore, it is imperative that first those role models should be convinced to quit smoking.

The aim of this study is to underscore the necessity of active participation of religious officials in the tobacco control effort by determining knowledge, attitude and behavior of religious officials towards smoking and the new tobacco law (NTL) in the central district of Kahramanmaras.

\section{Methods}

Religious services in Turkey are conducted by the Directorate of Religious Affairs, and performed by mufti (headofficer of religion). In the provinces, there are mosques for prayers, with services conducted by imams, and courses on the Quran conducted by educators. The present study was performed in Kahramanmaras Province, and included officials of religion. Kahramanmaras province, located in the eastern Mediterranean region, has a population of 1 million persons, with approximately 520,000 living in the city center. In total, 641 religious officials, 492 Imams and 149 Quran course instructors, work in the central district of Kahramanmaras. Each month, the Kahramanmaras Province Religious Affairs Head-officer (mufti) holds a meeting with all of the imams in charge in the city center, and also with the Quran course instructors. Permission was obtained from the Kahramanmaras Religious Affairs Center for the present study. A 32-item questionnaire was prepared and administered to Imams and Quran course instructors during these meetings. Participants were informed about the study before the meetings on October 16 and 17, 2010. Participation was voluntary and included 406 (all attendee of the meeting) of 641 officials of religion (63.3\%).

The survey aiming to assess knowledge, attitude, and behavior towards the NTL, were prepared. The questions evaluated the following characteristics and perceptions of the participants: sociodemographic status, smoking status, degree of addiction to smoking, smoking status at home, knowledge and opinion about the NTL, ruling of Islam on smoking, and thoughts about taking active part in tobacco control effort.
Standard survey forms were filled out by the participants under the supervision of the investigator. Our study was approved by the local ethics committee of our faculty.

Data were evaluated by computer with SPSS 15.0 package program for statistics. Chi-square test was used for statistical analysis. $\mathrm{p}<0.05$ was recognized as statistically significant for all values.

\section{Results}

Mean age for 406 people who participated in the study was 37.94 \pm 7.09 years (range: $21-63)$. Three hundredtwenty (78.8\%) of the participants were male, $86(21.2 \%)$ were female. Socidemographic characteristics of the participants are shown in Table 1.

Twenty-eight (6.9\%) of the participants were current smokers, 35 (8.6\%) were ex-smokers and 343 (84.5\%) were non-smokers. In terms of gender distribution, all the current smokers were male thus smoking rate for male participants was $8.75 \%$.

Eight point one percent of the participants had at least one smoker in their households. Most of the houses $(84.8 \%)$ with smokers were houses of the non-smoker participants. Twenty-three (82.2\%) of 28 smoking participants noted that they did not smoke in their houses.

About the ruling of Islam on smoking, 177 (43.6\%) of the religious officials noted that it was prohibited (haram), whereas 228 (56.2\%) said that it was unfavorable but not prohibited (makruh), and only one

Table 1 Sociodemographic characteristics of the participants $(n=406$ )

\begin{tabular}{lll}
\hline Sociodemographic characteristics & $\mathbf{n}$ & $\%$ \\
\hline Gender & 320 & 78.8 \\
\hline Male & 86 & 21.2 \\
\hline Female & & \\
\hline Occupation & 312 & 76.8 \\
\hline Imam & 94 & 23.2 \\
\hline Quran course instructor & & \\
\hline Education level & 3 & 0.7 \\
\hline Primary school & 96 & 23.6 \\
\hline High school & 280 & 69.0 \\
\hline University & 27 & 6.7 \\
\hline Master & & \\
\hline Age (year) & 66 & 16.3 \\
\hline $20-30$ & 230 & 56.6 \\
\hline $31-40$ & 110 & 27.1 \\
\hline$\geq 41$ & & \\
\hline Marital status & 29 & 7.1 \\
\hline Single & 375 & 92.4 \\
\hline Married & 2 & 0.5 \\
\hline Widow/widower & & \\
\hline
\end{tabular}


participant noted that smoking was permissible (helal) in Islam (Table 2).

Two hundred eighty-five (70.2\%) of the participants responded that people in their parishes saw them as a role model and asked them about the ruling of Islam on smoking. Regarding the attitudes of religious officials towards their parishioners demanding help about smoking-related problems, $4.2 \%(\mathrm{n}=17)$ noted that they did

Table 2 Knowledge, attitude, and behavior of the participants about smoking and the new tobacco law (NTL)

\begin{tabular}{|c|c|c|}
\hline & & \\
\hline \multicolumn{3}{|c|}{ Knowledge, attitude, and behavior* } \\
\hline & n & $\%$ \\
\hline \multicolumn{3}{|c|}{ What is your smoking status? $(n=406)$} \\
\hline Smoker & 28 & 6.9 \\
\hline Ex-smoker & 35 & 8.6 \\
\hline Non-smoker & 343 & 84.5 \\
\hline \multicolumn{3}{|c|}{ What is the ruling of Islam on smoking $(n=406)$} \\
\hline Helal & 1 & 0.2 \\
\hline Haram & 177 & 43.6 \\
\hline Makruh & 228 & 56.2 \\
\hline \multicolumn{3}{|c|}{ Religious officials should not smoke among public $(n=406)$} \\
\hline Agree & 390 & 96.1 \\
\hline Disagree & 16 & 3.9 \\
\hline \multicolumn{3}{|c|}{ Religious officials should be exemplary models by not smoking cigarette $(n=406)$} \\
\hline Agree & 397 & 97.8 \\
\hline Disagree & 9 & 2.2 \\
\hline \multicolumn{3}{|c|}{ Smoking is an important health issue of Turkey $(n=406)$} \\
\hline Agree & 394 & 97.0 \\
\hline Disagree & 12 & 3.0 \\
\hline
\end{tabular}

Religious officials should participate in the campaigns against smoking $(n=406)$

\begin{tabular}{lcc}
\hline Agree & 375 & 92.4 \\
\hline Disagree & 31 & 7.6
\end{tabular}

Have you heard of the new tobacco law? $(n=406)$

\begin{tabular}{lll}
\hline Yes & 346 & 85.2 \\
\hline No & 60 & 14.8 \\
\hline Do you have adequate knowledge on the new tobacco law? (n = 406) & & \\
\hline Adequate & 192 & 55.5 \\
\hline Inadequate & 154 & 44.5
\end{tabular}

Do you support the new tobacco law? $\left(n=346^{* *}\right)$

\begin{tabular}{lll}
\hline Yes, I support & 326 & 93.4 \\
\hline No, I do not support & 20 & 6.6 \\
\hline Where did you gain knowledge about the new tobacco law? $(\mathbf{n}=\mathbf{3 4 6 * *}$ & & \\
\hline Television & 326 & 94.2 \\
\hline Newspaper & 150 & 43.4 \\
\hline Internet & 61 & 17.6 \\
\hline Friend & 43 & 12.4 \\
\hline Radio & 25 & 7.2 \\
\hline Healthcare workers & 21 & 6.1 \\
\hline In-service training & 18 & 5.2 \\
\hline School & 3 & 0.9 \\
\hline
\end{tabular}

* There was no statistically significant difference between the Imams and Quran course instructors ( $p>0.05$ ).

**60 people who were not aware of the new tobacco law were not included. 
nothing, whereas $87.4 \%(\mathrm{n}=355)$ told us that they informed them, $4.4 \%(\mathrm{n}=18)$ told that they referred them to authorized centers for further information, and $3.9 \%$ noted that they had never faced such a demand.

According to the Fagerström nicotine addiction test, $22(78.6 \%)$ individuals were low level and $6(21.4 \%)$ were moderate level addicts. 27 (96.4\%) of those people noted that they considered to stop smoking, whereas 20 (71.4\%) stated that they would like to have assistance for smoking cessation.

In terms of knowledge level of the participants about the NTL enacted in 2009, 346 (85.2\%) participants were aware of it. 154 (44.5\%) of those 346 people noted that they had inadequate information about the law, whereas $326(94.2 \%)$ people said that they supported the law (Table 2).

Among the participants who were aware of the NTL, 18 had learnt it from the in-office training, whereas 326 from television, 43 from a friend, 25 from radio, 3 from a teacher, 21 from a healthcare worker, 150 from newspaper, and 61 from the internet (Table 2).

Three hundred ninety (96.1\%) of the religious officials stated that they should not smoke in presence of other people and 397 (97.8\%) of them said that they should constitute an exemplary model by not smoking cigarette. Moreover, 394 (97.0\%) of the participants recognized smoking as an important health issue of Turkey and 375 (92.4\%) of the participants said that they should take active roles in the tobacco control effort (Table 2).

Three hundred (73.9\%) of the religious officials noted that they could be helpful in programs promoting smoking cessation. However, 389 (95.8\%) of them stated that they had no adequate knowledge on the subject and 271 (66.7\%) expressed a wish to receive training on assistance for smoking cessation.

\section{Discussion}

The influence of religion over health is taught in medical, nursing, public health, and theology schools [10]. The studies of the Eastern Asia Office of World Health Organization indicate that when used in combination with other activities, support of religious officials may benefit in prevention of some diseases and conditions $[11,12]$. In a study conducted by Yong et al. on smokers among Muslims in Malaysia and Buddhists in Taiwan, $61 \%$ of Muslim and 58\% of Buddhist participants were found to believe that religious officials could be of assistance in smoking cessation [13]. The studies of Saeed et al. and Swaddiwudhipong et al. showed that religious officials could increase the motivation of smokers who try to quit smoking $[14,15]$. Another study conducted by Buddhist monks yielded similar results, as well [16]. In our study, $73.9 \%$ of the religious officials noted that they could contribute to the campaigns on smoking cessation. After establishing the appropriate platforms, religious officials can be helpful in the tobacco control effort.

Currently, nearly one third $(31.2 \%$ - around 16 million) of adults older than 15 years of age smoke tobacco in Turkey [17]. In a study conducted by Family Research Institute and Turkish Statistical Institute (TUIK) in 2006 , the daily smoking rate among people $\geq 18$ years of age, was found to be $33.4 \%$ [18]. In terms of occupational groups, smoking rate was determined to be $41.9 \%$ for the police officers [19] and $45.8 \%$ for the physicians [20]. There are various studies focusing on smoking rates in various professions. In the study of Sezer et al., smoking rate among physicians and dentists in Elazig province was $54.9 \%$ for men and $39.5 \%$ for women. Ozturk et al. conducted a similar study on government officials in Kayseri province and found the smoking rate as $59.1 \%$. Fidan et al. found the smoking rate among teachers in Kahramanmaras province as 32.5\% [21-23]. In our study, smoking rate among religious officials in the central district of Kahramanmaras province was $6.9 \%$. This is a significantly lower rate compared with those of the general population and other occupations. Such a low smoking rate among religious officials suggests that religion and religious officials should be utilized for maintenance of public health in terms of preventive medicine.

In the present study, 27 of 28 smoking religious officials had a wish to quit smoking, whereas 20 were observed to be ready for outside help on this subject. Therefore, authorized people tasked with assisting people in smoking cessation should be informed and those officials should be encouraged in their effort on tobacco control. Tobacco smoking is an important public health issue. In many occupations, cigarette smoking is widespread which presents negative role models for the general population [24-27]. Some of those occupational groups are more important than others in terms of smoking. Those groups which are recognized as role models due to their status (eg. physicians, teachers, artists and sportsmen) should be aware of their responsibility towards the public. In a study performed in Ankara in 1995 on occupational groups looked upon as role models, smoking rate was found to be $50.8 \%$ in teachers, $43.9 \%$ in physicians, and $34.9 \%$ in sportsmen [28]. After this date, studies including 12.500 people from various occupational groups such as drivers, artists, police officers, physicians, media workers, deputies, Imams, and muezzins, were performed in 1998 and 1999, both of which revealed a varying smoking rate between $24.8 \%$ and $74.3 \%$. As lowest smoking rates were observed among the religious officials $(24.8 \%$ in 279 male religious officials in 1999), highest rates were determined to be among drivers [29]. In another study, 
more than $90.0 \%$ of the participants defined religious officials as role models in terms of smoking and smoking cessation [13]. In the current study, $70.2 \%$ of the participants stated that their parishioners followed them as role models and asked questions about smoking.

In our study, among religious officials facing smoking people or individuals who require help for smoking cessation, $4.2 \%$ did nothing, whereas $87.4 \%$ informed those people about smoking, $4.4 \%$ referred them to authorized centers, and 3.9\% noted having no such experience. In order to be able to assist and encourage their mosque community, religious officials themselves should have knowledge about smoking. Moreover, small number of religious officials who referred people to the authorized centers, indicates an unawareness among the religious officials that should be addressed.

In the study of Yong et al. on smokers, 79\% of Muslims and $88 \%$ of Buddhists were found to believe that smoking cigarette is prohibited by their religion [13]. In the current study, $99.8 \%$ of the religious officials stated that smoking was either "haram" (prohibited by religion) or "makruh" (not forbidden, but reprehensible). Moreover, $35(8.6 \%)$ of the participants noted that they had quitted smoking. $80 \%$ of those 35 individuals had quitted smoking within the recent decade which may be explained by the recent awareness campaigns, NTL, and recognition of smoking as "haram" or "makruh" by majority of the religious officials. As we consider the relatively higher smoking rates among healthcare workers who should be the leading role models and activists against smoking [30], participation of religious officials, among whom smoking rate is very low and smoking is believed to be prohibited by religion, in the tobacco control effort will be an important asset.

Turkey has ratified the FCTC and is taking steps to implement effective laws to control tobacco at the national level. In order to successfully execute and support this law, the government should follow a multidisciplinary and multisectoral approach by working in coordination with all the social institutions and components including non-governmental organizations, universities, mass media, and international organizations [31]. Since $94.2 \%$ of the participants in our study expressed their support towards the NTL and noted that they would readily support smoking cessation, religious officials may be counted as one of those social components, as well. Moreover, in a study conducted on physicians, their knowledge on therapies concerning tobacco addiction and the NTL, was found to be inadequate [32]. In our study, although majority of the participants (85.2\%) were aware of the NTL, $44.5 \%$ of them admitted having inadequate knowledge on the law. Those results suggest that even groups that should take the leading roles in the tobacco control effort do not have adequate knowledge about the NTL.

The majority of the participants who were aware of the NTL, had heard it from the mass media (Table 2). Since the reliability of information gained from the mass media is subject to discussion, it appears that the institutions that are responsible of informing the public about the new laws should work more efficiently.

Almost all of the religious officials in our study told us that they should constitute an exemplary model by not smoking among public. Additionally, nearly all the respondents recognized smoking as an important health issue for Turkey and expressed their conviction that they should play more active roles in the tobacco control effort (Table 2). Those results indicate the responsibility felt by religious officials in the effort to control tobacco.

Twenty-two of the 28 smoking religious officials were not smoking at home although it was not prohibited. This is an indication of the fact that smoking religious officials respect the health of family members. In the current study, $95.8 \%$ of the participants stated that their knowledge was not adequate on smoking and smoking cessation, whereas $66.7 \%$ expressed a desire to be trained on smoking and assistance for smoking cessation. Therefore, religious officials should receive training in tobacco control and on the contents of the NTL so that they may assist in educating the public about tobacco control regulations and the benefits of smoking cessation. Also they should take active roles along with the healthcare workers and other supporters in the tobacco control interventions. More importantly, they should be encouraged to contribute smoking prevention programs.

\section{Limitations and strength of the study}

All religious officials in our country are state employees and most of them are men. All religious officials attending to the monthly meeting accepted to fill out the questionnaire and attended to our study who constituted $63 \%$ of all religious officials in the city. The reason for low participation rate is the unattendance of some officials to the monthly meeting due to various excuses such as off day, authorized permission for health or being on duty. We believe that unattending officials did not affect our results, since they were not informed prior to the meeting. Thus the population in the meeting can represent all the religious officials in our city. On the other hand, these results give us information on the knowledge, attitudes and behaviors of religious officials in only one city on the NTL and this study does not represent whole Turkey. The strength of the study is the really low rate of smoking rate among religious 
officials, their willingness to be trained on the NTL and their capacity to access so many people.

\section{Conclusion}

In conclusion, due to low smoking rates and their esteemed status among public, religious officials should take an active part in smoking prevention, delivering smoking cessation counseling and smoking cessation campaigns in the leadership of healthcare professionals. Required legal framework should be built and appropriate platforms such as conducting training courses for health professionals and religious officials together could be an appropriate way of solution giving the leading role to health professionals in tobacco control.

\section{Ethics approval}

This study was approved by the local ethics committee of our faculty. Moreover, required permissions were obtained from the Muftiat of Kahramanmaras (council of muftis - highest religious local authority).

\section{Funding}

No funding.

\section{Acknowledgements}

This manuscript was presented as an oral presentation at the $10^{\text {th }}$ National Congress of Turkish Family Medicine, Mugla, Turkey, on 18-22 May 2011. The authors thank Prof. Dr. Yakup Gumusalan for his linguistic assistance.

\section{Author details}

'Department of Family Medicine, Medical Faculty, Kahramanmaras Sutcuimam University, Kahramanmaras, Turkey. ${ }^{2}$ Department of Public Health, Medical Faculty, Inonu University, Malatya, Turkey. ${ }^{3}$ Department of Chest Dieases, Medical Faculty, Kahramanmaras Sutcuimam University, Kahramanmaras, Turkey. ${ }^{4}$ Department of Public Health, Medical Faculty, Kahramanmaras Sutcuimam University, Kahramanmaras, Turkey.

\section{Authors' contributions}

MHS carried out the literature review and participated in the development of the study design, data management, data analysis, interpretation of the data, writing the article and revising article drafts for publication. AO participated in the development of the study design, interpretation of the data, and revising article drafts for publication. MC had the initial idea for the study and its design and participated in the development of the study design, interpretation of the data, and revising article drafts for publication. HK participated in the development of the study design, interpretation of the data. HCE participated in interpretation of the data, and revising article drafts for publication. All authors read and approved the final manuscript.

\section{Competing interests}

The authors declare that they have no competing interests.

Received: 21 April 2011 Accepted: 28 July 2011 Published: 28 July 2011

\section{References}

1. Warren CW, Riley L, Asma S, et al: Tobacco use by youth: A surveillance report from the global youth tobacco survey project. Bull World Health Organ 2000, 78:868-76.

2. World Health Report: 2002 Reducing risks, promoting healthy life. WHO, Geneva; 2002 [http://www.who.int/whr/2002/en/whr02_en.pdf], (accessed: 25.01.2011)
3. Azak A: Factors affecting the use of cigarettes by students of health officer. Toraks Derg 2006, 7(2):120-4.

4. Aşut Ö: Physician and smoking. Türk Tabipler Birliği Yayınları, Maya Matbaacılık Yayıncılık Ltd. Ști. Ankara, 1.Baski; 1993, 45-52.

5. WHO: Tobacco or Health in Turkey. Repeat of a WHO mission to Ankara, Turkey. 1997.

6. Bilir N: Level of tobacco control in Turkey. Tur Toraks Derg 2009, 10:31-4

7. Ministry of Health of Turkey: National Tobacco Control Program and Action Plan 2008-2012, Ankara. 2008 [http://www.saglik.gov.tr/TR/belge/16961/eski2yeni.html], (accessed: 27.01.2011).

8. Chapman S: Tobacco Control. BMJ 1996, 313:97-100.

9. Schwartz JL: Methods of smoking cessation. Med Clin North America 1992, 76:451-75

10. InterFaith Health Program. Emory University, Rollins School of Public Health; 2004 [http://www.hnpnet.org], (accessed: 25.01.2011).

11. Jabbour S, Fouad MF: Religion-based tobacco control interventions: how should WHO proceed? Bull World Health Organ 2004, 82:923-927.

12. El Awa F: The role of religion in tobacco control interventions. Bull World Health Organ 2004, 82(12):891-970[http://www.who.int/bulletin/volumes/82/ 12/editorial31204html/en/], (accessed: 10.06.2011).

13. Yong H, Hamann SL, Borland R, Fong GT, Omar M, for the ITC-SEA project team: Adult smokers' perception of the role of religion and religious leadership on smoking and association with quitting: A comparison between Thai Buddhists and Malaysian Muslims. Soc Sci Med 2009, 69:1025-31.

14. Saeed AAW, Khoja TA, Khan SB: Smoking behavior and attitudes among adult Saudi nationals in Riyadh City, Saudi Arabia. Tob Control 1996, 5:215-9.

15. Swaddiwudhipong W, Chaovakiratipong C, Nguntra P, Khumklam P, Silarug N: A Thai Monk: an agent for smoking reduction in a rural population. Int J Epidemiol 1993, 22:660-5.

16. Influence of religious leaders on smoking cessation in a rural population-Thailand, 1991. MMWR Morb Mortal Wkly Rep 1993, 42:367-9 [http://www.cdc.gov/mmwr/preview/mmwrhtml/00020671.htm], (accessed 26.01.2011).

17. The Ministry of Health of Turkey, Primary Health Care General Directorate: "Global adult tobacco survey Turkey Report-2010". [http://www.who.int/ tobacco/surveillance/en_tfi_gats_turkey_2009.pdf], (accessed: 26.01.2011).

18. Prime Ministry Republic of Turkey, General Directorate of Family and Socia Research, Turkish Statistical Institute: Family Structure Research, Ankara. 2006 [http://www.aile.gov.tr/files/AileYapıs1\%202006\%20.pdf], (accessed: 27.07.2011).

19. Kutlu R, Çivi S, Karaoğlu O: The Relationship Between the Frequency of Smoking and Depression among Police Officers. Kor Hek Derg 2008, 7:31-8.

20. Cirit M, Orman A, Ünlü M: Smoking Habits Among Physicians in Afyon. Toraks Derg 2002, 3:253-6.

21. Sezer E, Öztürk Z, Bilgin N: Smoking attitudes and behavior among physicians and dentists working in Elazıg. Doğa Turk J Med Sci 1990, 14:657-68.

22. ÖZtürk M, Ĕgri M, Eker HH: The Officers' smoking status and evaluation of this situation in terms of work environment in the district of Hacilar, Kayseri province of Turkey. Halk Sağ|ğı Günleri (Erişkin Sağ|ğı) Bildiri Kitabı, Samsun; 1995, 28.

23. Fidan F, Sezer M, Demirel R, Kara Z, Ünlü M: Smoking status of teachers and their attitudes about smoking restriction. Toraks Derg 2006, 7:196-9.

24. Kutlu R, Marakoğlu K: Evaluation of the prevalence and behaviors of the ex-smoker university students. Marmara Med J 2005, 1:17-23.

25. Trottier A, Brown J: Occupational medicine for policing. J Clin Forensic Med 1995, 2:105-10.

26. Smith DR, Devine S, Leggat PA, Ishitake T: Alcohol and tobacco consumption among police officers. Kurume Med J 2005, 52:63-5.

27. Maia DB, Marmar CR, Metzler T, Nobrega A, Berger W, Mendlowicz MV, Coutinho ES, Figueira I: Post-traumatic stress symptoms in an elite unit of Brazilian police officers: prevalence and impact on psychosocial functioning and on physical and mental health. J Affect Disord 2007, 97:241-5.

28. Bilir N, Doğan BG, Yıldız AN: Behaviors and attitudes about smoking. Hacettepe Halk Sağ|ı̆ı Vakfı Yayını No:7, Ankara; 1997, 73-91. 
29. Bilir N, Güçiz B, Yıldız AN: Smoking Behaviors and Attitudes. Ankara, Hacettepe Public Health Foundation, International Development Research Centre, Ankara; 1997.

30. Güneș G, Pehlivan E, Eğri M, Genç M: Prevalence of smoking in doctors, nurses, and medical faculty students working in Turgut Özal Medical Center. J Turgut Ozal Medical Center 1997, 4:407-12.

31. Bilir N, Çakır B, Dağlı E, Ergüder T, Önder Z: The report of tobacco control policies in Turkey. WHO 2010, Available from: 32. http://www.ssuk.org.tr/ pdf/TurkiyedeTutunKontroluPolitikalari.pdf (accessed: 26.01.2011).

32. Uysal MA, Dilmen N, Karasulu L, Demir T: Smoking habits among physicians in Istanbul and their attitudes regarding anti-smoking legislation. Tuberk Toraks Derg 2007, 55:350-5.

\section{Pre-publication history}

The pre-publication history for this paper can be accessed here: http://www.biomedcentral.com/1471-2458/11/602/prepub

doi:10.1186/1471-2458-11-602

Cite this article as: Sucakli et al: Religious Officials' knowledge, attitude, and behavior towards smoking and the new tobacco law in Kahramanmaras, Turkey. BMC Public Health 2011 11:602.

\section{Submit your next manuscript to BioMed Central} and take full advantage of:

- Convenient online submission

- Thorough peer review

- No space constraints or color figure charges

- Immediate publication on acceptance

- Inclusion in PubMed, CAS, Scopus and Google Scholar

- Research which is freely available for redistribution

Submit your manuscript at www.biomedcentral.com/submit 